\title{
Escape behavior in gravid and non-gravid females of Gonatodes albogularis (Squamata: Sphaerodactylidae)
}

\author{
Moisés E. Domínguez-López, ${ }^{1}$ Federico Pablo Kacoliris, ${ }^{2}$ and María Verónica Simoy ${ }^{3}$ \\ ${ }^{1}$ Fundación Ambiente Biodiverso, Calle \#7ª-47 Ofc. 202, Montería, Colombia. \\ E-mail: mdominguez@fundacionambientebiodiverso.org. \\ ${ }^{2}$ Sección Herpetología, Departamento de Vertebrados, Museo de La Plata, CONICET, Calle 122 y 60, La Plata (1900), Buenos \\ Aires, Argentina. E-mail: kacoliris@fcnym.unlp.edu.ar. \\ ${ }^{3}$ Instituto Multidisciplinario sobre Ecosistemas y Desarrollo Sustentable, Universidad Nacional del Centro de la Provincia de Buenos \\ Aires, CONICET, Paraje Arroyo Seco s/n, Tandil (B7000GHG), Buenos Aires, Argentina. E-mail: : vsimoy@gmail.com.
}

\begin{abstract}
Escape behavior in gravid and non-gravid females of Gonatodes albogularis (Squamata: Sphaerodactylidae). Theoretical models of predator-prey relationships describe tradeoffs between energetic and other costs of escape, effectiveness of escape behavior, and predation risk. These models predict that an animal will flee when the expected fitness cost due to risk of predation becomes equal to the the cost of the escape or post-encounter fitness is maximized, depending on the model. In this framework, several individual and ecological variables have been shown to affect escape patterns, but the effect of reproductive status has been studied in few species. We assess differences in escape behavior between gravid and non-gravid females of Gonatodes albogularis. Lizards were surveyed by applying a free search method along independent transects. For each lizard, we determined reproductive status as gravid or non-gravid and recorded several variables related to escape behavior. We made a discriminant function analysis to see whether the state of individuals affect escape behavior. Our results show that the escape variables distance fled, the final distance and the distance to refuge differ between gravid and non-gravid females. These findings support predictions based on risk and cost, but do not support models of flight initiation distance. Such differences could be related to a physiological process known as behavioral compensation, through which some individuals (gravid females in our case) modify their behavior to offset predation risk. Further studies are needed to see if behavioral compensation can be explained in terms of adaptive processes in G. albogularis.
\end{abstract}

Keywords: behavioral compensation, escape theory, escape behavior, predation risk.

\footnotetext{
Resumo

Comportamento de fuga em fêmeas grávidas e não-grávidas de Gonatodes albogularis (Squamata: Sphaerodactylidae). Modelos teóricos de relações predador-presa descrevem balanços entre custos de fuga (energéticos e de outros tipos), eficiência do comportamento de fuga e risco de
}

Received 22 November 2017

Accepted 04 June 2018

Distributed June 2018 
predação. Esses modelos preveem que um animal escapará quando o custo esperado em termos de sucesso reprodutivo devido ao risco de predação quando for igual ao custo de fuga ou quando o sucesso reprodutivo após o encontro for maximizado, dependendo do modelo. Nesse cenário, demonstrou-se que diversas variáveis individuais e ecológicas afetam os padrões de fuga, mas o efeito do status reprodutivo foi estudado em poucas espécies. Nós avaliamos diferenças no comportamento de fuga entre fêmeas grávidas e não-grávidas de Gonatodes albogularis. Os lagartos foram estudados aplicando-se um método de procura livre ao longo de transectos independentes. Para cada fêmea, determinamos o status reprodutivo como grávida ou não-grávida e registramos diversas variáveis relacionadas ao comportamento de fuga. Desenvolvemos uma análise discriminante para verificar se o estado dos indivíduos afetavam o comportamento de fuga. Nossos resultados mostram que as variáveis distância percorrida na fuga, distância final e distância para o refúgio diferem entre fêmeas grávidas e não-grávidas. Essas descobertas sustentam previsões baseadas em risco e custo, mas não sustentam modelos de distância de início de fuga. Tais diferenças poderiam estar relacionadas como um processo conhecido como compensação comportamental, por meio do qual alguns indivíduos (as fêmeas grávidas, no nosso caso) modificam seu comportamento para compensar risco de predação. Estudos adicionais são necessários para verificar se a compensação comportamental pode ser explicada em termos de processos adaptativos em G. albogularis.

Palavras-chave: compensação comportamental, comportamento de fuga, risco de predação, teoria da fuga.

\section{Introduction}

Interest in predator-prey interactions has led to the development of theoretical models, which assess the fitness costs of escape behavior in relation to the predation risk (Ydenberg and Dill 1986, Cooper and Frederick 2007). These models posit that an animal will flee when the risk of predation becomes equal to the cost of escape (Ydenberg and Dill 1986) or at the distance where expected fitness after the encounter is maximized (Cooper and Frederick 2007). Despite this quantitative difference in predictions, the two models make qualitatively identical predictions that the distance from a predator at which escape begins decreases as the cost of fleeing increases. Escape costs are primarily loss of opportunities to enhance fitness by engaging in other activities such as feeding or reproduction, but also include minor energetic costs (Martín and López 1999, Martín et al. 2003, Cooper and Pérez-Mellado 2004).

In addition to considering distance between prey and predator, these models also consider distance to a refuge (Bulova 1994) and allow predictions about the effects of numerous factors that can affect the escape behavior in lizards, including the microhabitat (Martín and López 1995, 2000, Cooper 1999, Cuadrado et al. 2001), size of the perch (Losos and Irschick 1996), thermal conditions (Carrascal et al. 1992, Stankowich and Blumstein 2005, DominguezLópez et al. 2015a), movement capabilities (Martín and López 1995, Domínguez-López et al. 2015b) and reproductive behavior or reproductive costs (Shine 1980, Bauwens and Thoen 1981, Schwarzkopf and Shine 1992a).

The reproductive state of individuals can affect escape success by a reduction in locomotion capabilities (e.g., reduced speed related to a higher weight in gravid females) (Bauwens and Thoen 1981, Brodie 1989, Schwarzkopf and Shine 1992a, Sinervo and DeNardo 1996). Several studies showed a higher vulnerability to predators by gravid rather than non-gravid females (e.g., Shine 1980, Bauwens and Thoen 1981, Seigel et al. 1987, Brodie 1989, Van Damme et al. 1989, Cooper et al. 1990, Schwarzkopf and Shine 1992a, Qualls and Shine 1997). Because reproductive state has a survival 
cost, some species have developed behavioral mechanisms to compensate for a reduction in locomotor capabilities (e.g., associated with gravidity) by increasing escape success when facing predators.

Behavioral compensation therefore, decreases cost associated with a reduction in escape success (Langkilde et al. 2005). In lizards, behavioral compensation can involve more time basking or foraging to compensate for increased energy requirements while regenerating autotomized tails (Dial and Fitzpatrick 1981), spending more time in refuge to compensate for increased predation risk (e.g., after tails have been autotomized) (Martín and Salvador 1993, Langkilde et al. 2005). Because behavioral compensation affects lizards' survival, it is of great relevance to demography. However, it has been little studied in Neotropical species.

The Yellow-head Gecko, Gonatodes albogularis (Duméril and Bibron, 1836), inhabits dry and wet tropical forests (Rivero-Blanco 1979, Köhler 2003, Schargel 2008). It occurs in several microhabitats including tree trunks, rock caves and foliage. It natural predators include larger lizards, some snake species, raptors, certain other birds and some mammals (Fitch 1973, Bello 2000). Gonatodes albogularis is diurnal with reproductive activity all year round. Females have an acyclical and asynchronous reproductive period and an invariable clutch size of one egg (Serrano-Cardozo et al. 2007). In this study we assess differences in escape behavior between gravid and non-gravid females of $G$. albogularis. We hypothesize that reproductive state, affects escape behavior of females $G$. albogularis regardless of modifying influences of individual differences in mass or size.

\section{Materials and Methods}

\section{Study Site}

The area is one of the last relicts of tropical forest located in the south of the Córdoba Department, Colombia $\left(08^{\circ} 04^{\prime} 48.7^{\prime \prime} \mathrm{N}, 75^{\circ} 42^{\prime} 28.4^{\prime \prime} \mathrm{W}\right)$.
We conducted our study in the Choco-Magdalena region, characterized as Dry Tropical Forest, with mean annual temperature of $28^{\circ} \mathrm{C}$ and seasonal rains (Hernández-Camacho et al. 1992).

\section{Surveys}

Fieldwork was conducted in March and April 2012, coincident with the period of highest activity reported for this species (SerranoCardozo et al. 2007). We surveyed lizards using a free search method, walking along parallel line transects (with a separation of $10 \mathrm{~m}$ between them) from 09:00 to 17:00 $\mathrm{h}$. When an individual was found, one observer (always the same) simulated a predatory attack by approaching the gecko directly, at the same speed $(1 \mathrm{~m} / \mathrm{s})$ until it fled. The distance between the researcher and the lizard when the researcher began to approach was $5 \mathrm{~m}$. The approaching researcher stopped moving as soon as the lizard started to flee and remained still until the lizard stopped fleeing. For each observation we recorded the following variables: flight initiation distance (FID): distance between the lizard and the observer in the moment when escape started; distance fled (DF): distance between the first location of the lizard and its location at first stop after escaping; final distance (FD): distance between the observer and the point at which the lizard stopped moving or the point at which the lizard went into hiding; distance to refuge (DR): distance between the first location of the lizard and the closest shelter (ground caves, rocks, trunks, or foliage) (Bauwens and Thoen 1981, Bulova 1994, Vanhooydonck et al. 2007). Quantitative data were recorded using a tape measure with $1 \mathrm{~cm}$ accuracy.

While one observer recorded escape variables, the second observer captured the individual and recorded snout-vent length (SVL) and tail length (TL), using a dial caliper with 0.1 mm accuracy; mass (M), using a scale with 0.01 $\mathrm{g}$ accuracy; sex, on the basis of external features; age, classified as adult and juvenile on the basis of the minimum size at sexual maturity (30.1 
$\mathrm{mm}$ for males and $31.7 \mathrm{~mm}$ for females; SerranoCardozo et al. 2007); and reproductive state of females, classified as gravid and non-gravid, on the basis of external features. Females were identified as gravid by the presence of an egg, which can be easily recognized by examining the abdominal side visually and by palpation (Domínguez-López pers. com.).

\section{Data Analysis}

We used a combination of multivariate analysis, ANCOVA and Generalized Linear Models (GLM), to assess whether the individual state (gravid and non-gravid) affects escape behavior. However, because escape behavior might be also related to individuals' variables such as SVL, TL and/or M, we firstly tested for differences in these variables between gravid and non-gravid females, using Two-tailed Student t-test. Because $M$ showed differences between females' states, we included it as a covariable in the analyses.

To assess the differences in escape behavior between females' states in a broad sense, we performed a multivariate analysis using as covariates FID, DF, FD and DR. However, considering that states might be shaped by differences in $\mathrm{M}$ among individuals, we performed two discriminant analysis, with and without $\mathrm{M}$ as covariate, to see the contribution of escape variables in both cases.

We tested assumptions of homoscedasticity and normality for all the escape variables. In the case of FID and DF, we had to apply transformations to the data as $\log$ FID and $\log (\mathrm{DF}+1)$ in order to meet assumptions. We then performed an ANCOVA to compare both FID and DF between gravid and non-gravid females, including $M$ as a covariate. In the case of FID we also checked for a potential effect of $\mathrm{DR}$, since this variable could be also shaping a state effect. Due that an ANCOVA showed that DR and FID have an interaction $(p<0.05)$, we decided to perform Generalized Linear Models (GLM) with a Gaussian distribution to assess if the individuals' state, $\mathrm{M}$ and/or DR significantly affect FID.

In the case of FD and DR, even transformed data failed in meeting the assumption of normality, thus we decided to apply GLM with a Gaussian distribution, to assess the relationship between these variables and individual's state plus $\mathrm{M}$ as explanatory variables. For all the tests, we considered a $p<0.05$ as significant.

\section{Results}

We recorded escape data for 95 females, among which 37 were gravid and 58 non-gravid. We observed differences in all the escape variables measured when comparing between gravid and non-gravid females (Table 1). Considering the individual variables, a Twotailed Student t-test showed significant differences in $\mathrm{M}$ between gravid and non-gravid females ( $\mathrm{t}: 9.37 ; p<0.05$ ), but no differences in SVL (t: $0.47 ; p=0.64)$ or in TL (t: $0.41 ; p=$ $0.59)$ were observed.

Both discriminant analyses showed a good separation between gravid and non-gravid females and the contribution of escape covariates where similar. In the analysis that considered M as covariate, the eigenvalue that represents the variation of the direction of greatest variation of the data was of 20.18 and reconstructed $100 \%$ of the total variability with a single canonical discriminant function given by $F=-8.57$ $2.89 \mathrm{DF}-5.86 \mathrm{FD}+6.42 \mathrm{FID}-0.54 \mathrm{DR}+0.59 \mathrm{M}$.

The centroids in the discriminant space show that the groups are opposed in the canonical axis at values of gravid $=5.57$ and non-gravid $=-3.55$ and the cross-classification (Table 2) shows that the state allows to discriminate the observations in an almost perfect way since the classification given by the discriminant function coincides $100 \%$ with the one given by the state. From the discriminant function standardized by common covariances, it can be seen that $M$ is the least important variable for discrimination, indicating that escape variables are the most important to separate both groups (Table 3). 
Table 1. Mean \pm SD values for the individual and escape variables assessed in both gravid $(\mathrm{G}=37)$ and non-gravid $(\mathrm{NG}=58)$ females. SVL, snout-vent length; $M$, mass; TL, tail length; FID, flight initiation distance; DF, distance fled; FD, final distance; DR, distance to refuge.

\begin{tabular}{|c|c|c|c|c|c|c|c|}
\hline \multicolumn{4}{|c|}{ Individual variables } & \multicolumn{4}{|c|}{ Escape variables } \\
\hline & SVL & $M$ & $\mathrm{TL}$ & FID & DF & FD & DR \\
\hline G & $32.96 \pm 0.7$ & $4.85 \pm 0.1$ & $31.54 \pm 0.5$ & $3.93 \pm 0.4$ & $1.40 \pm 0.1$ & $2.00 \pm 0.5$ & $2.05 \pm 0.6$ \\
\hline NG & $32.90 \pm 0.7$ & $4.33 \pm 0.3$ & $31.46 \pm 0.5$ & $2.48 \pm 0.3$ & $1.15 \pm 0.2$ & $1.46 \pm 0.2$ & $2.94 \pm 0.5$ \\
\hline
\end{tabular}

Table 2. Cross-classification and apparent rate of error.

\begin{tabular}{lcccc}
\hline Group & Gravid & Non-gravid & Total & Error $(\%)$ \\
\hline Gravid & 37 & 0 & 37 & 0.00 \\
Non-gravid & 0 & 58 & 58 & 0.00 \\
\hline Total & $\mathbf{3 7}$ & $\mathbf{5 8}$ & $\mathbf{9 5}$ & $\mathbf{0 . 0 0}$ \\
\hline
\end{tabular}

Table 3. Discriminant functions data standardized by common covariances. FD, final distance; FID, flight initiation distance; DF, distance fled; $\mathrm{DR}$, distance to refuge; $M$, mass.

\begin{tabular}{lc}
\hline Covariate & Relative importance \\
\hline FD & -2.15 \\
FID & 2.13 \\
DF & -0.42 \\
DR & -0.28 \\
M & 0.16 \\
\hline
\end{tabular}

Overall, the specific analyses performed for each escape variable indicated that FID, DF, and FD were significantly larger for gravid than for non-gravid females, while DR was significantly shorter in gravid females (Figure 1). In the case of FID and DF, ANCOVAs analyses showed that although $\mathrm{M}$ has an effect on escape behavior, significant differences between individual states exists, even after controlling for the effect of $\mathrm{M}$, with values of $F=214.75$ and $F=400.07$ respectively $(p<0.05)$. A GLM showed that $\mathrm{M}$ does not affect FID $(p<0.05)$, but this variable is affected by state (gravid and non-gravid) and DR $(p<0.05)$. Similar results were obtained for
FD and RD, where GLM analyses showed that variations in these variables were only explained by individual state (gravid and non-gravid) but not by $\mathrm{M}$, with $p<0.05$.

\section{Discussion}

Overall, our research confirms that reproductive status affects escape behavior in $G$. albogularis. Among the variables included in the discriminant model, the final distance and the flight initiation distance were the most important to separate gravid and non-gravid-females. Although the mass of individuals was different between states, this variable showed a poor support in separating groups with respect to the escape variables.

The differences observed between gravid and non-gravid females might be related to a physiological process known as behavioral compensation, through which some individuals (gravid females in our case) change their behavior to balance costs and benefits in avoiding predators (Cullum 1998, Ghalambor et al. 2004, Husak et al. 2006).

In lizards, gravid females have a clear disadvantage when facing predators in relation to non-gravid ones; the above is because when they become heavier, they become slower (Shine 1980, Van Damme et al. 1989). This decrease in escape abilities can be compensated ecologically by triggering escape earlier and/or by perching closer to shelter.

Values of FID in G. albogularis were larger in gravid than non-gravid females. These results are at opposite with studies in other reptile species, where gravid females delayed their 

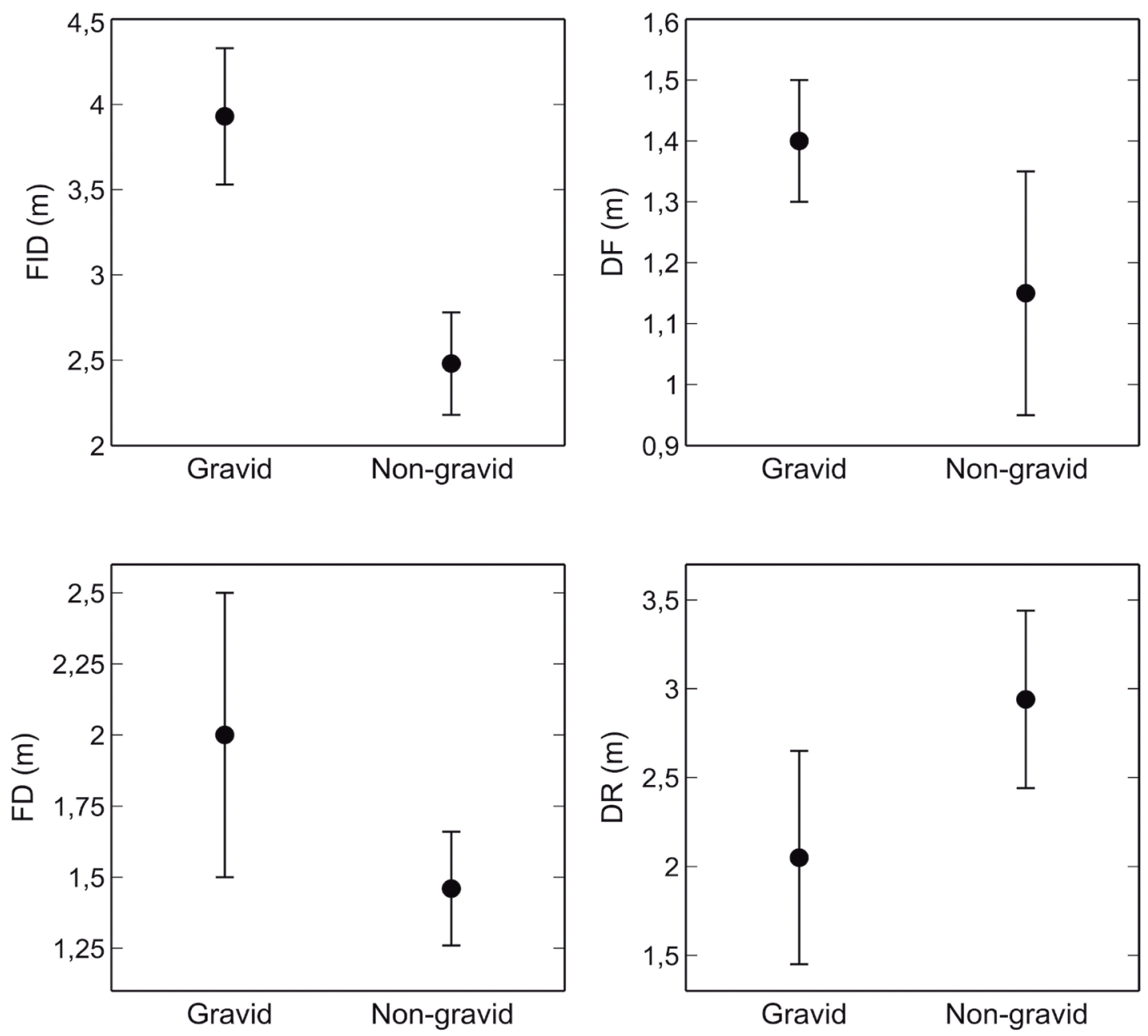

Figure 1. Comparison of escape behavior between gravid and non-gravid females. FID, flight initiation distance; DF, distance fled; FD, final distance; DR, distance to refuge. The data is presented as mean \pm SD.

escape, allowing a closer FID (Braña1993, Blázquez 1995, Charland 1995, Charland and Gregory 1995). A larger FID allows a higher chance of avoiding predators' attacks, as seen in other studies (Bauwens and Thoen 1981, Schwarzkopf and Shine 1992a, b). Although not assessed in this study, we assume a behavioral compensation that might result from a decrease in velocity of gravid females, as seen in Bauwens and Thoen (1981) and Sinervo et al. (1991). Although this behavioral change could affect access to food and thermoregulation sites, the survival advantage likely outweighs costs (Shine 1980, Seigel et al. 1987, Sinervo et al. 1991, Lailvaux et al. 2003). Behavioral differences observed in non-gravid females most likely are related to reproduction, feeding, and microhabitat use. Our results support optimal escape theory proposed by Ydenberg and Dill (1986).

When confronted by a potential predator, gravid females ran further than non-gravid ones. It is possible that gravid females may run further 
to put a greater distance between them and the pursuit predator, which may provide a survival advantage that offsets the energetic cost of running a greater distance while carrying an egg. An alternative explanation might be that nongravid females may not run as far because they can outpace a predator even if it gets close to them. This could be related to habitat structure and complexity, as seen in other studies (Martín and López 1995, 2000, Cooper 1999, Cuadrado et al. 2001). Yellow-headed geckos start to flee earlier in microhabitats lacking suitable refuges, especially when on rocks, but also on leaf litter (Domínguez-López et al. 2016). Moreover, although cryptic females could be undetected in leaf litter, this microhabitat is not a good refuge, because predators can locate a concealed prey there (Martín and López 2000, Capizzi et al. 2007). Previous observations on $G$. albogularis showed that females perch closer to shelter than males (Domínguez-López et al. 2015a) and that they prefer to pair with those males that offer microhabitats structurally more complex (Domínguez-López et al. 2016). Future studies should assess in more detail whether the observed differences are related to habitat complexity, reproductive state, or both.

Differences in escape behavior related to reproductive state have also been observed in other lizard species. For example, some sit-andwait species use a lower amount of energy when feeding (contrary to widespread foragers) but not when facing predators, as seen in Crotaphytus collaris (Say, 1823) (Husak et al. 2006) and some female Anolis (Losos and Irschick 1996, Irschick 2000). Females may spend more energy in escaping than in feeding and probably this situation increases in gravid females. However, these gravid females could compensate these energetic costs by changing their behavior (Bauwens and Thoen, 1981, Brodie 1989, Cooper et al. 1990). In G. albogularis, further studies are needed for a deep understanding of the causes associated with the observed patterns and to determine whether behavioral compensation can be explained in terms of adaptive processes.

\section{Acknowledgments}

This work was supported by the project "Caracterización de aspectos ecológicos y conductuales de especies comunes de anfibios y reptiles en fragmentos de bosque seco y zonas urbanas del departamento de Córdoba". FK and MVS salaries are covered by Consejo Nacional de Investigaciones Científicas y Tecnológicas (CONICET).

\section{References}

Bauwens, D. and C. Thoen. 1981. Escape tactics and vulnerability to predation associated with reproduction in the lizard Lacerta vivipara. Journal of Animal Ecology 50: 733-743.

Bello, R. 2000. Anolis sp. and Gonatodes albogularis (Yellow-headed gecko). Predation. Herpetological Review 31: 239-240.

Blázquez, M. C. 1995. Body temperature, activity patterns and movements by gravid and non-gravid females of Malpolon monspessulanus. Journal of Herpetology 29: 264-266.

Braña, F. 1993. Shifts in body temperature and escape behaviour of female Podarcis muralis during pregnancy. Oikos 66: 216-222.

Brodie, E. D. I. 1989. Behavioural modification as a means of reducing the cost of reproduction. American Naturalist 134: 225-238.

Bulova, J. 1994. Ecological correlates of population and individual variation in antipredator behavior of two species of desert lizards. Copeia 1994: 980-992.

Capizzi, D., L. Luiselli, and L. Vignoli. 2007. Flight initiation distance in relation to substratum type, sex, reproductive status and tail condition in two lacertids with contrasting habits. Amphibia-Reptilia 28: 403-407.

Carrascal, L. M., P. López, J. Martín, and A. Salvador. 1992. Basking and antipredator behaviour in a high altitude lizard: implications of heat-exchange rate. Ethology 92: 143-154.

Charland, M. B. 1995. Thermal consequences of reptilian viviparity: thermoregulation in gravid and nongravid garter snakes (Thamnophis). Journal of Herpetology 29: 383-391.

Charland, M. B. and P.T. Gregory. 1995. Movements and habitat use in gravid and non-gravid female garter snakes (Colubridae: Thamnophis). Journal of Zoology 236: $543-561$. 
Cooper, W. E. 1999. Tradeoffs between courtship, fighting, and antipredatory behavior by a lizard, Eumeces laticeps. Behavioral Ecology and Sociobiology 47: 54-59.

Cooper, W. E. and W. G. Frederick. 2007. Optimal flight initiation distance. Journal of Theoretical Biology 244: 59-67.

Cooper, W. E. and V. Peréz-Mellado. 2004. Tradeoffs between escape behavior and foraging opportunity by the Balearic lizard (Podarcis lilfordi). Herpetologica 60: 321-324.

Cooper, W. E., L. J. Vitt, R. Hedges, and R. B. Huey. 1990. Locomotor impairment and defense in gravid lizards (Eumeces laticeps): behavioural shift in activity may offset costs of reproduction in an active forager. Behavioral Ecology and Sociobiology 27: 153-157.

Cuadrado, M., J. Martín, and P. López. 2001. Camouflage and escape decisions in the common chameleon Chamaeleo chamaeleon. Biological Journal of the Linnean Society 72: 547-554.

Cullum, A. J. 1998. Sexual dimorphism in physiological performance of whip tail lizards (genus Cnemidophorus). Physiological Zoology 71: 541-552.

Dial, B. E. and L. C. Fitzpatrick. 1981. The energetic costs of tail autotomy to reproduction in the lizard Coleonyx brevis (Sauria: Gekkonidae). Oecologia 51: 310-317.

Domínguez-López, M. E., F. J. Diego-Rasilla, and A. M. Ortega-León. 2016. Effects of sex and microhabitat structure on escape behaviour in the diurnal gecko Gonatodes albogularis. Animal Biology 66: 31-47.

Domínguez-López, M. E., F. Kacoliris, and A. M. OrtegaLeón. 2015a. Effects of microhabitat temperature on escape behavior in the diurnal gecko, Gonatodes albogularis (Duméril \& Bribon, 1836) (Squamata: Sauria: Sphaerodactylidae). Herpetozoa 28: $49-54$.

Domínguez-López, M. E., A. M. Ortega-León, and G. J. Zamora-Abrego. 2015b.Tail autotomy effects on the escape behavior of the lizard Gonatodes albogularis (Squamata: Sphaerodactylidae), from Córdoba, Colombia. Revista Chilena de Historia Natural 88: 1.

Fitch, H. S. 1973. A field study of Costa Rican lizards. University of Kansas Science Bulletin 50: 39-126.

Ghalambor, C. K., D. N. Reznick, and J. A.Walker. 2004. Constraints on adaptive evolution: the functional tradeoff between reproduction and fast-start swimming performance in Trinidadian guppy (Poecilia reticulata). American Naturalist 164: 38-50.
Hernández-Camacho, J., A. Hurtado-Guerra, R. OrtizQuijano, and T. Walschburger. 1992. Unidades biogeográficas de Colombia. Pp. 105-152 in G. Halffter (ed.), La Diversidad Biológica de Iberoamérica I: Programa Iberoamericano de Ciencia y Tecnología para el Desarrollo. Xalapa. Instituto de Ecología A.C., Acta Zoológica Mexicana.

Husak, J. F., J. M. Macedonia, S. F. Fox, and R. C. Sauceda. 2006. Predation cost of conspicuous male coloration in collared lizards (Crotaphytu scollaris): an experimental test using clay-covered model lizards. Etholology 112: $572-580$.

Irschick, D. J. 2000. Effects of behaviour and ontogeny on the locomotor performance of a West Indian lizard, Anolis lineatopus. Functional Ecology 14: 438-444.

Köhler, G. (ed.). 2003. Reptiles of Central America. Herpeton, Verlag Elke. Offenbach, Germany. 367 pp.

Lailvaux, S. P., G. J. Alexander, and M. J. Whiting. 2003. Sex-based differences and similarities in locomotor performance, thermal preferences, and escape behaviour in the lizard Platysaurus intermedius wilhelmi. Physiological and Biochemical Zoology 76: 511-521.

Langkilde, T., R. A. Alford, and L. Schwarzkopf. 2005. No behavioural compensation for fitness costs of autotomy in a lizard. Austral Ecology 30: 713-718.

Losos, J. B. and D. J. Irschick. 1996. The effect of perch diameter on escape behaviour of Anolis lizards: laboratory predictions and field tests. Animal Behaviour 51: 593-602.

Martín, J. and A. Salvador. 1993. Thermoregulatory behaviour of rock lizards in response to tail loss. Behaviour 124: 123-136.

Martín, J. and P. López. 1995. Avian predation on a large lizard (Lacerta lepida) found at low population densities in Mediterranean habitats: an analysis of bird diets. Copeia 1996: 722-726.

Martín, J. and P. López. 1999. An experimental test of the costs of antipredatory refuge use in the wall lizard, Podarcis muralis. Oikos 84: 499-505.

Martín, J. and P. López. 2000. Costs of refuge use affect escape decisions of Iberian rock lizards Lacerta monticola. Ethology 106: 483-492.

Martín, J., P. López, and W. E. Cooper. 2003. When to come out from a refuge: balancing predation risk and foraging opportunities in an alpine lizard. Ethology 109: 77-87.

Qualls, F. J. and R. Shine 1997. Geographic variation in 'costs of reproduction' in the scincid lizard Lampropholis guichenoti. Functional Ecology 11: 757-763. 
Rivero-Blanco, C. 1979. The Neotropical lizard genus Gonatodes Fitzinger (Sauria: Spherodactylinae) Unpublished Ph.D. Dissertation, Texas A\&M University, College Station, Texas, USA.

Schargel, W. 2008. Species limits and phylogenetic systematics of the diurnal geckos of the genus Gonatodes (Squamata: Sphaerodactylidae). Ph.D. Dissertation. The University of Texas at Arlington, Arlington, Texas, USA.

Schwarzkopf, L. and R. Shine.1992a. Costs of reproduction in lizards: escape tactics and susceptibility to predation. Behavioral Ecology and Sociobiology 31: 17-25.

Schwarzkopf, L. and R. Shine.1992b. Thermal biology of reproduction in viviparous skinks, Eulamprus tympanum: why do gravid females bask more? Oecologia 88: 562 569 .

Seigel, R. A., M. M. Huggins, and N. B. Ford. 1987. Reduction in locomotor ability as a cost of reproduction in snakes. Oecologia 73: 481-465.

Serrano-Cardozo, V. H., M. P. Ramírez-Pinilla, J. E. Ortega, and L. A. Cortés. 2007. Annual reproductive activity of Gonatodes albogularis (Squamata: Gekkonidae) living in an anthropic area in Santander, Colombia. South American Journal of Herpetology 2: 31-38.
Shine, R. 1980. 'Costs' of reproduction in reptiles. Oecologia 46: $92-100$.

Sinervo, B. and D. F. DeNardo. 1996. Costs of reproduction in the wild: path analysis of natural selection and experimental tests of causation. Evolution 50: 12991313.

Sinervo, B., R. Hedges, and S. C. Adolph. 1991. Decreased sprint speed as a cost of reproduction in the lizard Sceloporus occidentalis: variation among populations. Journal of Experimental Biology 155: 323-336.

Stankowich, T. and D. T. Blumstein. 2005. Fear in animals: a meta-analysis and review of risk assessment. Proceedings of the Royal Society B: Biological Sciences 272: $2627-$ 2634.

Van Damme, R., D. Bauwens, and R. Verheyen. 1989. Effect of relative clutch mass on sprint speed in the lizard Lacerta vivipara. Journal of Herpetology 23: 459-461.

Vanhooydonck, B., A. Herrel, and D. J. Irschick. 2007. Determinants of sexual differences in escape behavior in lizards of the genus Anolis: a comparative approach. Integrative and Comparative Biology 47: 200-210.

Ydenberg, R. C. and L. M. Dill. 1986. The economics of fleeing from predators. Advances in the Study of Behavior 16: 229-249.

Editor: Jaime Bertoluci 